\title{
社会的合意形成と文理の二人三脚 ${ }^{\dagger}$
}

\section{桑予 敏雄*}

\section{1. 文矅の喃会}

1990年代に大きな変化を被った日本の高等教育では、 いわゆる大学の「大棡化」と「重点化」の荒波が洗う なか、「総合」や「国際」「環境」などのキーワードを 冠した大学学部や大学院研究科がつぎつぎに生み出さ れた。境界的、あるいは横断的な研究領域に関わらさ るをえないこれらの組織は、従来型の伝統的な学問の 名を付しな学部・学科や大学院研究科・尃攻とは異な り、21世紀の兴問のありカを融合の時代へと推し進め る、あるいは推し進めるべき力をもたなければならな いとだれもが考えていた。

少子化による短大の四大化、学部学生定員およひ教 官定員の削減、それに平行して行われた教善課程解体 にもかかわらず、大学バブルの時代が八○年代後半以 降のバブル経済の時代に遅れてやってきたことには、 十分な理由がある。就職先のない大学生を収谷するた めの大学院増設である。

経済活性化の名の下に大量につぎ込まれた補助金行 政は、いわゆる国土事業に限られたものではなかった。 補助金による公共事業が地方白治体の財政恵化をもた らしたように、教育につぎ込まれる補助金の額もまた 国の大きな支出項日であり、効率的、效果的運用が求 められた。

ところが、公共事業のありカが綮しく批判され、新 しい方向が模索されてはいるものの、試みられる㱏業 の多くが態依然とした制度的基盤のトで行われてい るように、学際的、融合的学問もまた、時代の要請に もかかわらず、四来の制度基盤のもとで連営されてい る。なぜなら、新領域の学部学科が創設され、大举院 尃攻が開設されても、新しい学科や尃攻の研究を正学 に評価するシステムが久けたまま、21世紀に突入した からである。評洒を子算に結びつけるべき科兴研究費 の学問分類は、時代の変化に对応したものになってお らず、既存の評価システムを保持している。

たしかに、融合的研究を促進する研究助成もないで

$\uparrow$ Social Consensus Building and the Collaboration of Humanities and Technology

Toshio KUWAKO

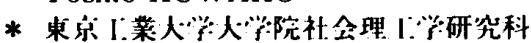

Tokyo Institute of Technology
はないが、融合的研究に対する評洒が「文理の接点が 明確でない」という程度のものであれば、䊅局評価す る側に文理融合ができていないので、タテマエはいく ら融合的であっても、ホンネの部分では既得権益のな かでの評価である。「勲章はりえられる者にとってより

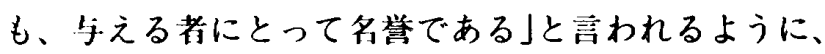
融合的であると評価されることよりも、融合的である と評価することのほうがはるかに難しい。若い人々か 融合的な研究に進むことに网難さを感じている大きな 理由がここにある。

研究助成の多くが計䤑評洒主義をとっているこ上も 人きな䦗題である。光初の計画のなかで進めていた研 究から独創的なアイデアが生まれることがあるが、計 邮評価主義では、その芽を伸ばすことはできない。な ぜなら、光初計画のなかに含まれていなかった方向に 研究の方向を転換することは、当初計画からの逸脱に なってしまうからである。そこで、融合の試みも独創 的な研究を生み出すような計悯ではなく、当初から達 成叮能な融合的研究を甘標とするか、あるいは、異分 野の研究者の交流を企画するものにすぎない。

以上のような状洗のなかで行われているのが融合の 試みである。そのような融合的な試みの一つの方向と して、近代的な合理的主義を人間と社会に適用するこ とで文理融合を標榜する学開がある。19世紀的な功利 主義的人間観を基礎に置き、'うえられたルールのなか で自しの利益を最大化することを合理的であるとして 社会システムや経済システムを捉えようとする研究、 あるいは、ルールの押しつけをできるだけ排して自己 の利益を最大化してよいとする価值観にもとづいた意 思決定の研究である。これらは、方法という点での文 理融命的研究ということができる。

だが、従来型の人間観や社会䆏そのものがいま大き な課題に直面していることもまた事実である。なぜな ら向しの利益を第一の目標としては考えず、むしろ自 分の利益はほどほどにし、他う、他者の利益を先に置 き、あるいは自しの利益を儀牲にすることを生き甲斐 と考える人々が増えており、そのような俩值観を基礎 とする社会のありカが求められているからである。

円しの利益を考えるまえに、他の人間のこと、他の 牛物とのこと、そしてそれらと自分との関保性を基整 
に考える思想は、近代が否定した前近代的な思想の復 活のようにも見える。日本でいえば、嘿徳太子以来、 文化の根翰に位䍌してきた仏教思想はその典型である。 自己の娪りをさておいて、苦しむ人々の救済を先にす

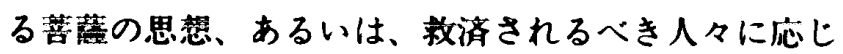
て自己の瓷を変化させる観音の思想は、自我の確立と 自己の利得の最大化」をめさす近代的人間像の対極に ある。

人間中心の经済合理性やイデオロキーによって人々 の洒值雉を制御しようとする20世紀的思想は過去のも のになりつつある、というのがわたしの認識である。

人間以外の生物をも含む多裸な存在の価值を其存させ る期代、あるいは其存させなければならない時代が 2 1 位紀であり、この意味での「融合」の時代像が求め られている。この融合は既存の社会的行動ルールだけ でなく、人間や社会に対する思考パ夕ーンをしばりつ けているルールを反省して、新しい社会のビジョンを 描く創造的な融合でなければならない。この創造的活

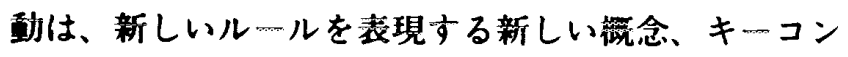
セでトの創造という謻题をも負うことになるであろう。 ところがいわゆる科学的といわれる定量的な锶測や計

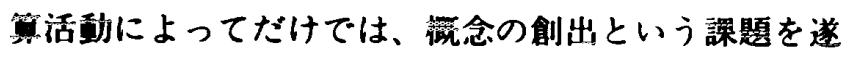
行することはできない。とするならば、この課题にこ そ、照合㬐代の学問研究のあり方が示哮されているよ うに思われる。ルールとそれを構成するコンセプトの 創造はどのようなものであるへきなのか。文理の二人

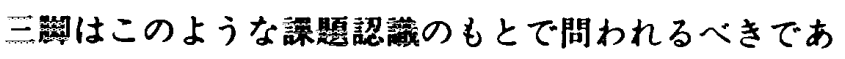
る。

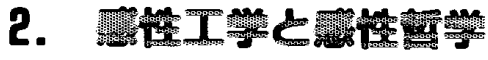

「所与のルールに従って自己の利㚇を最大化する存 在」という人間像にもとづく文理融合的研究ではなく、 自己と他者との閔係性を基綢にして学問と人間の関係 を捉之ようとするのか、わたしの理解する感性工学で あり、留许哲学である。ここでいう「他者」には他の ひと、他のモノ、あるいは㻴境の全体性が含まれる。

罦境と人間、社会と人間との相互関係やネットワーク こそかこれからの人間と世界とを捉える梘点であると するならば、息性という切り口によって文理の融合は どのような意䣡を与えられるのだろうか。感性工学と 感往哲学の閔你のなかに含まれるこれからの文理融合 のヒントについて考えてみよう。

「感许」とは何か。わたしは感性を「自己と環境と の相阙性を觉知する能力」と考えている。たとえば、

「うるおい」や「やすらぎ」のような感性語は、散歩 コ一スとなっている裹の性質でもなく、またそこを散 步するわたしの心の性質でもなく、森とわたしの関倸
性の性質である。感性とはこの関係性を捉える能力で ある。感性工学はもともと感性をべースにした讋品開 発を目指したものであったか、現在では、モノづくり だけでなく、都市嘖境をはじあとする謤境全体、ある いは社会システム全体を对象とする学問となっている。 また感性哲学は、その理念を「衣食住から買境・生命・ 请報に至る感性の関わる領域での、社会のビジョンを つくるコンセプト・ワーク」とし、感性工学の哲学を 提案するとともに、哲学そのもののまなさしを机上の テキストから社会の現寒へと向け変える力となりつつ ある。

感性工学と感性哲学との関保に見られるような文理 融合の方向性は、「工学が哲学を呼び込んでいること」 のうちにある。この意味を問うことがここでの第一の 課題になる。なぜ工学は哲学を呼び込むのか。その理 由は二つ存在する。

ます、工学が自己の存在の根找を問い始めたという ことがある。この問いは、技術とは何か、および科学 とは何かという問いとも不可分な関係にある。

たしかに科学とは何かという問いは、近代科学の成 立のときにも問われている。西洋㗼界では、教羕によ る恩籠の真理から科学的探求の自向の精神を解き放つ ために不可欠で根源的な問いであった。科学とは客筑 的な真理の探究であり、自然の光である理性によって 獲得される崇高なものであった。だが、それだからこ そ、近代科学の成立時には、同し真剣さをもって技術 とは何かという問いが立てられたことはなかった。技 術の役目はある意味で自明のことだったからである。

しかし現代社会では、「科学とは何か」という問いを 「土学とは何か」、技術とは何か」という問いから独 立の問いとして問うことはできない。工学的知譩や技 術が科学研究に不可分に組み込まれているからという 理由だけではない。科学と工学・技術の本質か問われ るとき、つねに杜会との関係において、そして社会を とりまく地球謤境との関係において問われるという点 で、相互に区別することができないからである。

純粋に見える科学研究がれ自体で自然を客制的に 研究できると考えることはもはや不可能である。どの ような研究開発も人間の行為である以上，悬体的な制 約を、したかって時空的な制約を受ける。この時空的 制約は、地球罩境の上での時空的条件にもとづくもの であるか、社会のなかの人間の行為であることに変わ クはない。䍗境と社会の制約を排除して、純粹な理論 的能力をもつ合理的人間として科学研究に㩲わること ができると考えることは、一穆の幻想であり、近代的 人間が行ってきた自然の真理をあらゆる柬總から解放 されて追い求めることができる者という、自己の抽鱼 
化に基づいている。

地球環境と社会からの制約のもとでエ学が自らを問 おうとするとき、この問いは、士学を研究し、㐫用し、 そのことによって社会や地球環境を作りかえようとす る人間の行為に向かうことになる。人間は下学的知識 を用いることによって、地球環境に、社会に、そして めぐりめぐって自分自身に何をしようとしているのか。 この問いがけっして、丁学にとって外在的な問いでは ないということが、いま工学自身の直面している状況 なのである。工学はその内部性において自らの存在を 問い始めている。

では、工学によって発せられた哲学的な問いに応し ることができるのは、いったい誰であろうか。1学が 自らの存在の意義を問うことによって、20世紀的な I: 学のあり方から抜け出ようとするとき、20世紀的な枠 に収まった哲学には、この問いに呼応することはでき ない。哲学が細かな言語分析や孤独な実存分析に時を 費やし、あるいは、特定の世界粺や人間観によって武 装されたイデオロギーの論争に身を任せた時代は過ぎ 去った。哲学もまた「学と同しように、学問的な行為 として、地球環境と社会のなかの存在として、みずか らを問わずにはいられないのである。哲学が自己の身 を他者との相互性の認識のもとに置こうとするとき、 すでにそれは20世紀的な思考の枠組みから脱している。 こうしな思考だけが、自らの存在を問おうとする「学 的思考と出会うことができる。

合理的で孤独な存在としての自己から出発するのが デカルトであり、他者と折り合いをつけるルールのな かで自己の快楽を最大化することを肯定するのが功利 主義であった。どちらの思考でも、自己とそれを取り 囲む環境との相互関係が後回しになるのは当然である。 自己を問うことと環境を問うこととは別々のことだか らである。しかし20世紀の経験から学んだ人々だけが 確認することができるのは、自己への問いと環境への 問いとが別々のものではないということである。環境 と自己の関保はつねにダイナミックに変化しており、 そのような関係性のなかで自己も他者も概念化される。 自己の利益を最大化するときに準拠するルールは、本 来ならば、つねに流動するこの関係性のもとで形成さ れるべきものである。あらかじめルールが与えられて いると考えられたのは、地球環境が無限の資源をもち、 廃棄物をいくら排出しても環境は污染されず、どれは ど熱を放出しても極地方の氷が融けるなどとは想像も できなかったからである。だが、いまや自己の利益を 最大化することが自己の存在を根底から脅かしている ということを人間は認識しなくてはならない。つまり、 自己の利益の最大化を制約するルールを定めようと思
つても、そのルールそのものは、自しの利益を最大化 してよいという前提に市ってはもはや定めることがで きないのである。

1兴は人間の社会を便利にするための手段であると いわれるかもしれない。しかしこの手段が寒は、与え られたルールを前提するのである。そのルールルそのも のが手段の行使によって崩壤するリスクを抱え込んで いるとすれば、「学は目しの行為を規制するルールそ のものを問わずにはいられない。たとえば、生命工学 は、そのことによって人間と地球にいったい何をしよ うとしているのだろうか。いったい何をしようとする 伎在であるのか。どのようなルールのもとで研究をし、 また応用することで、この养はは学として存立して ゆけるのか。

自己と環境との相五関係を捉える能力、それが感性 である。感性工学は、人間の感性にもとづいて工学を 人間化しようとする。すなわち、人間を環境との相関 的な存在と捉え、そしてそのような関係性のもとに、 感性を「学の基礎としようとする。人間が感党的な对 象に対してどういう態度をとろうと寸るのか、感覚さ れる世界全体、つまり環境全体に対してどのような姿 势をとろうとするのか、それを明らかにし、よりよい 闺係性の構築に向けて、知を働かすのである。

ここで指摘しなければならないことは、人間と環境 とのよりよい関係性を構築するということが感性工学 の重要な任務だということである。よりよい関係の構 築ということには、価值判断が含まれる。「科学技術を どう使うかは科学技術の問うべきことではない、それ は社会の問うべきことだ」という19世紀・20世紀的な 発想はもはや通用しない。感性という洒值判断を含む 能力を「学的思考のなかに位置づけることによって、 感性厂骂は、みずからが価值判断の主体であることを 選びとるのである。この選択は、あるべきモ人、ある べき人間関係、あるべき社会、あるべき環境に対する 積極的な価值判断の主体であることを自認することで ある。ここにたんなる道具の制作学としての従来型工 学:との決別が存在する。だからこそ、感性工学の根底 には、学のあるべき姿を問う動機付けが内在するの である。【学はどのような洒值をめさすべきか、工学 は何のためにあるのか、感性「学が感性哲学を要請す る第二の理由は、このような問いである。

「兴とは何か、学は何をめさすべきか、本質への 問いと目的への問い、この二つの問いにおいて、工学 が哲学を呼び込む。この「呼び込み」において工学が 哲学と二人三脚で進もうとするのである。 


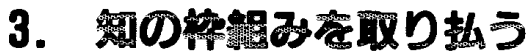

本質と目的への問いに応えることができるのはどの ような思考だろうか。本質と目的への問いは、時代の 流れのなかで出現してきたものであり、この問いにど う応えるかという課题に对して普過的な解答は望めな い。わたしは、大きな轱换のなかで時代の流れをどう 捉えるかということについて、平安時代末から跣倉時

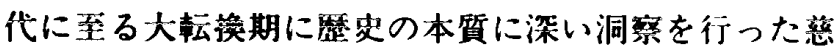
円の考えから学ふことか大きいと考えている。

慈山の思想は、時代の变化には大きな罍勢があって、 その骨格となる流れを捉えることが重要だということ である。12 世紀末、天皇家と籐原氏による支配体制 から武家政権へと変わる時代の転換のなかで、多くの 人々は時代の変化の本筫を捉えきれず、旧来の体制の

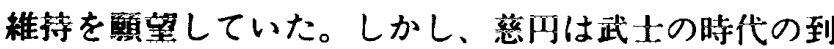
来を堐史の本貿と捉え、それに備えるべきことを説い たのである。

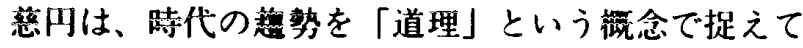
いる。道理は、決して璴灾全体を貫いていると想定さ れる理念的なものではない。歷史は多檬な要素を含み ながら、タイナミックに展開してゅくものであり、単 一の縟要法則やそれを表現する単純なイデオロギーに よって把握されるようなものではありえない。目の前

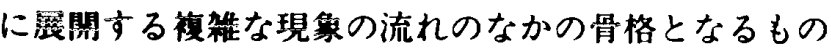
を捉えることができなければ、つきの時代の基本的な 道䉘を予测することもできず、それに对する対応の方 法も見いだすことはできない。

慜円は、大きな時代の変化のなかで対応できる人材 の発掘成と、能力のあるひとが迅速かつ適切な意思 決定を行うことができるような制度基盤を重要な課題 に学げている。既存の枠にとらわれた洒做判断と意思 決定は、畤代の変化に適切に对応することを不可能に してしまうからである。

では、わたしたちは、跱代の变化というものをいっ たいどのように捉えるべきなのだろうか。わたし自苞 にとって、「文理の二人三紼というタイトルで請演し ていること自体か時代の変化というものを感しさせる 一つの現急である。工学系の学会で哲学を論じ、と いうことが、すでに述へたように、工学そのものが自

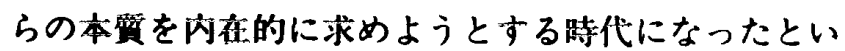
うことを示している。工学そのものがまったく他なる 文系の学問からテイデアの提供を受けるということで ななく、むしろ内在的な自己理解に向けてともに考え る琶榙を求めるという意味での二人三脚であるとわた しは認塣している。

と同時に、哲学そのものにとっても、こうした異な
つた分野との関わりは、異なった分野からの外的なア イデアの提供を求めるということではなく、むしろ㫪 学が内在的な変化を求めているということの証左でも ある。

わたしは「哲学」ということばを用いたが、ここで の「哲学」はとても広い意味で用いている。慈円の整 史帮学について論した『西行の風景】という本のなか で、わたしは、『新古今和歌集』で最多の収録歌数を残 した西行と第二位の慈订との友情の背後にある共有の 思想を明らかにしようとしたか、その思想を読み解く ためには、既存の歴史学や文学、宗教学などの垣根を 取り払うべきだと考えた。哲学も磨皮学も文学も宗教 举も問題そのものに向かってその思考を結集しなけれ ばならないのである。とくに既存のルールが立ちゅか なくなり、新しいルールをもとめて時代が動こうとす るとき、既存の領域の枠組みによって思考していたの では、変化の本質を捉えることはできないからである。 つまり、文系の学問間の垣根も取り払わなければなら ないのである。文理の二人三瞅ということばが意味し ているのは、問題そのものが要求する知の枠組みの「取 り执い」である。

垣根を取り払うことは、言うは易く行うは難い。議

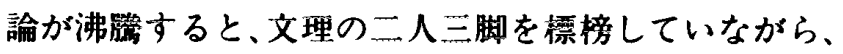
「わたしの立場からいうと」とか「そちらの方は尃門 ではありませんので」とか「わたくしどもの考え方で は」というような言葉使いが出てくるからである。最 後の「わたくしども」というのは、たんに「わたし」 の複数を意味しているのではなく、自分の属する組織、 專門分野、あるいは学会を代表するかのような表現で ある。問題はそのような「わたくしども」という表現 を捨て、「わたしは」という一人称単数で語ることがで きるかどうかである。もちろん、この「わたし」もそ れぞれの立場に立っている。正場がかたくしども」 という表現への強制力をもっている。しかし、立場に 拘泥していては「わたし」に赴くことはできない。「立 場」に立って問影をつかむだけではなく、他の立場に 立って解沈策を提案できることが重要である。

以上.の狱態を別の表現で描くならば、それぞれがそ

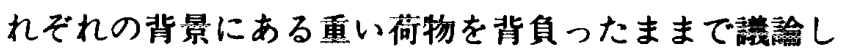
ようとすれば、その重みに振り回されてしまって、創 造的な議論を行うことはできない、まず、それぞれの 荷を降ろし、身整な精神になって、問題に取り組むこ とが必要だということである。

文系と理系の学問は、それぞれの片足に重しにつけ たままでは、二人三脚で走ることはできない。二人三 脚することができるのでは、文系と理系の学問ではな く、あるいは、それぞれに属する個々の学問分野では 
ない。むしろ、新しい二人三脚は、文系、理系の学閣 を研究するそれぞれの研究者個人の結びつきによって 発生する。ここでは、融合的思考のできるひとりひと りの研究者が問題である。あるいは、それはもはや研 究者というべきでない。ちょうど行政官が同時に市民 であるように、研究者も地球上に生きる市民である。 研究者としての立場を相対化できる市民どうしの二人 三脚のなかに新しい学問の融合が可能になる。それが できないのであれば、文理の二人二脚は、すぐに抽象 的な研究原則の間の抗争と妥協に終わってしまうであ ろう。

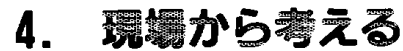

方法としての文理融合、あるいは文理の二人三脚と いうことについてはすでに触れた。わたしがもうひと つ文理の二人三脚、あるいは、文理融合と考えている のが、現場からの要請である。社会の現実が文理の双 方を同時に必要としているということである。

現場からの文理の融合を要請するものとして、近年 とくに実感されるのが合意形成の問題である。「合意形 成」というのは、ある事柄について異なった意見をも つものどうしが話し合いの末に意見の一致を見ること であるが、ここでとくに重要なのは、「社会的合意形成」 である。

「社会的合意形成」ということで意味しているのは、 道路や河川、あるいは情報ネットワーク、そのほか社 会全体の活動を支える社全基盤や制度基盤の形成に関 して、従来型の国家主導や行政主導ではなく、暴なつ た意見をもつ市民が計画から奏行、そして評洒に主る プロセスに参加し、意思決定に何らかの形で関りおする ことを意味する。社会的合意形成の現場が文理の二人 三脚を要求しているのである。

ここで「市民」ということばについて触れておきた い。さまさまな領域で市民とはだれかということが開 われている。とくに公共事業への汸民参加ということ が言われる。関連して語られることにP．Ｉ．(パブり ック・インホルブメント）ということがある。ここで いわれるパブリックとは、影響をうける地域住民や地 域外住民、行政步凬、参加を推進するクループなど、 公共事業に関上するすべての人々を意味する。したが って、「市民」と「パブリック」とは同じ概念ではない。 パプリックには、行政当后も含まれるが、市民には、 行政官は含まれないからである。だが、行政官も让場 としては行政官ではあっても、はやり一人の人間とし て発言する可能性ももっている。このとき発言するひ とりの人間のことを「市民」と呼ぶことができる。し たがって、沛民は住民とも翼なる。地域に倠んでいな
くても、閏題に関心をもつならば発言の権利をもつの であり、そのような発言の主体が市民である。重要な のは、行政官もまた艮民であるということであり、有 識考あるいは学識経験者というけ場に立つ大学研究者 もまた一人の市民だということである。

さて、国土行政や環境行政をめぐって、行政と地域 体民あるいは地域外の市民との間で論争が、さらには 紛争が発生している。行政对住民という対立図式のな かで重要な役割を果たすのが研究者である。研究者は しばしば学識経験者として意胃を求められる。この意 味で、社会的意思決定に大きく関与してきた存在であ る。研究者には中立的な奖勢が求められてきたが、そ の中主性は、しばしば「科学的」という表現に置き換 えられていた。

だが、21世紀に入り、科学的であることと中立であ ることとがー体であると必ずしも単純に前提できなく なっている。中立的であったはずの1学的研究が「市 死参加」や「合意形成」の研究に着手しているからで ある。

I゙学のなかでも自然環境と社会環境の再編に最大の おをもってきたのが土机养であり、建築学であり、 また造園学:である。造園学は、もともと庭園を研究の 課題としていたのであるが、現在では都市景䚇やまち づくりに深く関わっている。これらのて学的分野は、 従来型の研究では、作品としての木:木施設、建造物、 都市景観などを対象としてきた。しかし、いま、この ような学問がまったく新しい場面に遭遇している。士 木1:学が书民参加や合意形成といった社会とのかかわ りにその関心を问けさるをえなくなっているからであ る。

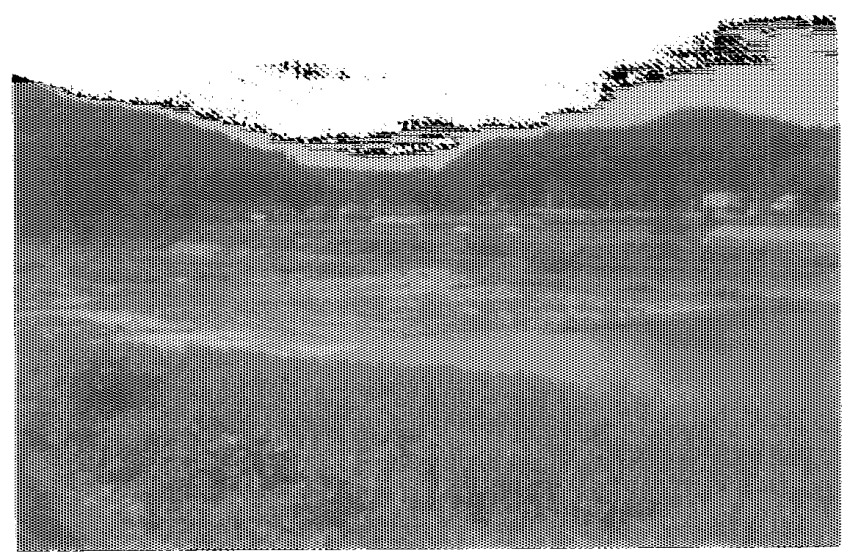

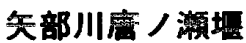

一つの例を考えてみよう。儿州知部川には、多くの

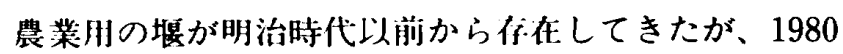
作代から90年代に伀統的な摭に代わって叮動式の堰が 
作られた。利水という点からより効槒的なシステムに 組み替えるためである。そうすることで起きた一つの 現柔が注目される。その一つは、従来の伝統的な摼を 水か流れ下るときに水が泡立ち、酸素が供給されてき たのが、新しい塻ではそれがほとんどなくなってしま ったということである。可動堰の建設時に生態系につ

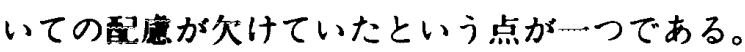

もう一点は、伝統的な塻の維特管理は地域住民の手 で行われていたが、近代的な䣅がそのような基同作策 を不要のものにしたということである。基同作業が不 必要になるのと平行して、地域の水文化もまた消隇す るという置命をたどった。河川や湖沼あるいは泉の近 くには、水神、幚神や茾天の社が多く建てられ、その 維特管理や祭礼の關催によって地域住民の水罯境に対 する意㗧向上に役方っていたのであるか、近代化は、 そのような文化だけでなく、水に対するリスク意讙ま で希濝なものにしていったのである。安全や効染を実

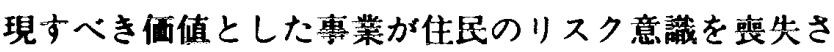
せるという効果を生むこともまた考虑されなかった。

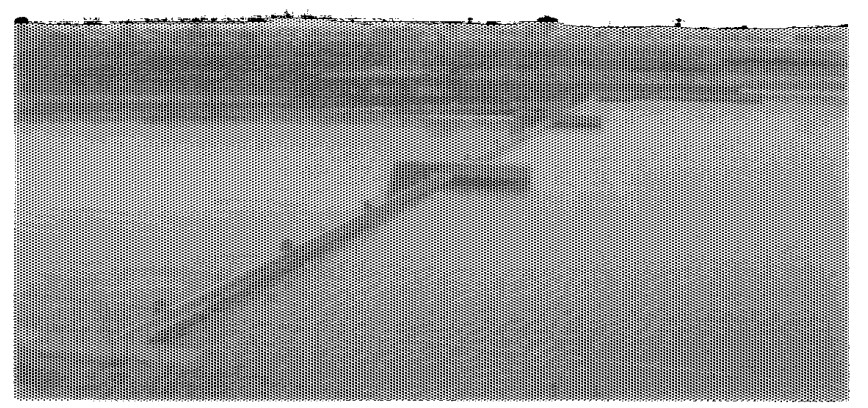

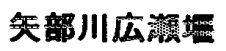

Uとつの土木專藌が生態系に大きな影整を与えると ともに、自然と生望系への住意荿や地域社会のあり 方にも変化をもたらすのである。土木工学は、その学

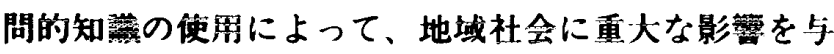
えることを学問内部の問題として問うことを求められ ている。すなわち、士学かその本質と目的とを内部か ら問う赫代が到来しているのである。

公其票菜とは、公共性を標搒しつつ近代士木技術を 行使して热間を大谟模に再編する行為である。空間の 大谋模な改変か人々の謤境に大きな変化をもたらす。 この改变の目的は、便利で快適な生活や経済的な発荹 という、後日本が自明としてきた洒值に結びつき、 だれもがの緹びつきそのものを問うことのないまま 孉程してきた。しかし、昨今の市民參加の高まりは、 自分たちは国士に何を刻してきたのかということに人々
が気づき始めたことを意味している。いつたい自分た

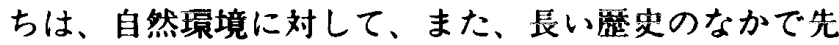
人たちがつりあげてきた空間に対して何をしてきた のか。とくに、戦後高度経済成長時代にその青春を送 り、反体制的な思想のなかに生き、研究者として、あ るいは企攀戦士として日本の国土改造に薏進してきた 人々が、1970年代から1980年代にかけて、自分たちの 国土に行ってきたことの意味を再び問い始めているの である。まちづくりや地域活動のなかで行政とかかわ リながら、一定の距離を蟞き、市民の立場から国土と 罢境を考えようとするひとびとがホランティテ活䡃や N P O活動に援わっている。

企業人としての立場や行政官としての交場から籍れ、 一汸医としての江場に立って摆境と社金を考えようと する人々の增加は、科学技術を地球匴境や国土然間人

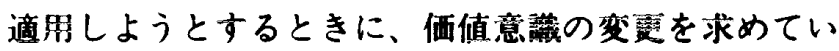
る。行政、アカデミズム、N P Oなどのかかわりのな かで、篥境への行為、社会への行為はどうあるべきか が問われるのであるが、科学技術の研究に匴わる者は、

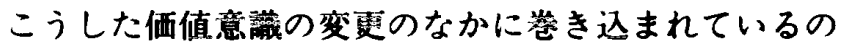
である。科学的知見の社会への提供という科学技街者 の社会的賣任がのような公範な関係者の討境のなか に加わらさるをえないからである。社会のなかでの科 学技術とは何であるのか、そしてそれは何を目的とし ているのかということか科学技術自奥の内在的な問い として立てられることが慗請されている。

いま述べたような状況そのものが本質への問いと目 的への問いという重琶な課題を提起する。本質と目的 という二つの課题は、ここでまた哲学的思考を求めて いる。本質と目的とは、哲学的思考が古代キリシテで 自然についてその考察のまなさしを向けたとき、また 中国で人生と社会について問いを発したとき、ともに その根幹にあったものであるが、科学技街と䁲境、科 学技街と社会との閣係性がそれぞれの本質と目的への 問いを呼び起こすのである。

学問の中主性についてもう少し考えてみるならば、 すでに述べたように、たとえば、土木土学か、济民参 加や合意形成、あるいは倫理の研究を行うようになっ

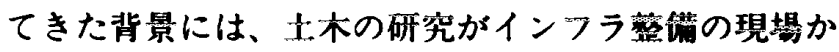
ら、また、そのような社全基盤を整错するプロセスか

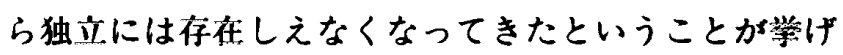
られる。国家主等、行政主尊の国土政慗のもとで研究

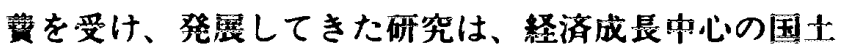
政策に深く閴わってきたことで、国土を経済発瑟の手 段として捉え、愢界に誇ることのできる日本の自然䁏 境に大きな変化をもたらした一主体であると考えるこ とができる。 
もちろん、国土の変化は、学閥だけによるものでは なく、政治、行政、産業界、あるいは国民白身もこの ような「列島の改造」に向けてばく進してきたことの 当然の結果でもある。現場に立って、わたしたちが一 体何をしてきたのかを閣おうとするとき、学閵研究も また中站性の名のもとに、そういった国术の変貌に侕 担してきたこともまた事実である。

市民参加や合意形成といった課題は、環境の問題に 对する市民からの問いかけに科学技術が、あるいは科 学技術者が社会の要請に応ずる必要を実感しはじめた ということを意味する。

科学技術の社会との関わりでもう一つ注目される点 は、科学研究にしろ、研究成果の社会的な応用にしろ、 その事業推進のプロセスにも大きな関心が集まってい るということである。できあがった構造物の価值より も、その構造物を最終目的とする計画段階からの進行 プロセスの価値が問われているからである。とするな ら、ここでもまた完成段階での構造物の価値を前提と するI学研究は、その構造物の建設に導くプロセスへ と関心を移ささるをえない。建設プロセスは、行政と 地域住民だけの関心の対象ではなく、事業の推進のた めの財源の提供者、つまり納税者としての国民全体の 関心事である。関心をもつ人々すべてのまなざしのも とで、どのようにプロセスを進めるのか、その進行の 管理の方法や技術が問われているのである。

21 世紀の公共事業では、どのような建造物ができた かということよりも、どのようにその建造物をつくつ たかということがはるかに重要な評洒指標になるであ ろう。この場合、どのようにつくったかという問いは、 けっして「学的技術のことだけを開題にしているので はない。社会基盤をつくるということは、社会とのか かわりのなかで、また、人々の関心のもとで、計画段 階から完成段階、さらに完成した建造物の管理プロセ ス、活用プロセスまで含めた、広いプロセス管理のも とにあるからである。このプロセスは、いま述べたよ うに、尃門家の占有事項ではない。進行プロセスに関 心をもつすべてのひとびとを巻き込む形で進めなけれ ばならない。

合意形成は、沛民、行政、尃門家など、さまざまな 人々がそれぞれの立場から問題の本質を見極め、その 站場を離れて可能な解決策を探索し、異なった意見を 出し合い、対立を克服し、合意に達するという一連の プロセスである。このとき、異なった意見の仔在は、 より高度な合意の達成のためには、なくてはならない 要素である。しかし、意見の違いは、对立を生み出し、 对立は反日を引き起こし、紛争の火種となることがし ばしば見られる。せっかく间じテーブルに就きながら、
手続きはの不手際によって封議が滞り、目的の合意に 到達できないことも多いのである。ここでのキーワー ドは「信頼」である。信頼のないところに円滑な議事 の進行はありえず、㺫滑な議事なくしては、関係者の 満足のいく決定には達しえない。信頼こそが合意に至 るもつとも基本的な条件である。

と闬時に、立場に固着する対市を克服するためには、 市場を越えて納得できる第三の選択肢を見いださなく てはならない。この選択肢の発見過程には、当事者の 対立の本質を見極め、その根底にある洒值意識を表に 出し、きちんと討議のテーマとして取りトげるだけの 技術が必要である。

わたしは合意形成プロセスの研究をもっとも重要な テーマに揭げているが、このことは、現場で行政と市 民との对話から合意を導くためにはどうしたらよいか という問題にHタ格闘している人々がわたしとの共同 研究を求めているということに根拠をもっている。河 川行政や道路行政、地域の情報ネットワーク構築とい つた現場で市民と行政の間で間題そのものに直面して いる人々は、問題そのものの再解釉と再定式を求めて いる。問題を掘り起こし、新しい理論の構築によって 問題解決の指針にしたいと考えている。

さて、現場で活動している多くの人々が理系出身で ある。河川にかかわるコンサルタント、行政で瓄境や 都市計画に関わる人々、環境情報のネットワークを構 築しようとする人々、そういった多くの人々は工学系 の研究から社会との接点を見いだそうとしている。そ うした人々がいわば行政の哲学、行政の倫理、さらに は、合意形成の理論化といった領域の問題を考之よう としている。わたしがいま合意形成の問題に挑戦しよ うと考えているのは、まさにそういう現場からの要請 である。

\section{5. 栖侕システムの二人三}

行政や企業と同様に、学開研究もまた組織のなかで 行われている。大学や研究所、あるいは学会などの組 織である。それらの組織に属し、組織の評洒基準によ って評価されることによって、研究者は研究を進める ことができる。だが、組織が時代の変化に合わなくな ってきたとき、向らの研究をどのように進めればよい のだろうか。

これは、非常に難しい閣いである。なぜなら、組織 の価値基準から逸脱するような研究を当の組織は評価 することができないからである。新しい発明やいまま でにない特許によって評価される場合は別である。し かし、川システムの評価基淮に準拠している人々はあ まりに斬新なアイデアを評価することはできないから 
である。

最初に述べたように、皟音は与えられる者にとって よりも、与えるものにとっての名誉である」といわれ る。とすれば、敌究そのものを文理の二人三街で行う よりも、箇究の評佰を文理の二人三脚で行うほうが り効果的であろう。評洒の基㸺や方法が变化してゆけ は、評洒される方は、おのずから変化してゆくからで ある。問題はどのように評価そのものを文理の二人三 藏で行うことかできるかということである。

評佰における文理の二人三脚という譟题は、すでに 述へたように、地球環境や社会、そして自己自身への 大きな影留をもつ学的な学問の内部から要請される

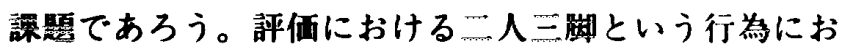
いても、行為の本薜と目的とがつねに問われなければ ならない。

行為の本蝢を問わなければならないという要請に応

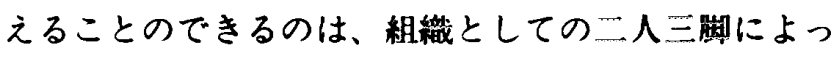
て文理融合を標搒する組織ではなく、組織や立場を維 れて価值判断できるひとびとからなる評価クループで あろう。それはつねに現場に直面し、問题を正視し、 その理論化を志す人々であることが望ましい。経験と 理論とはここでのもっとも重要な要索である。文理の 融合を可能にする評俩システムは、現寒を面視しなが ら高度な理論的能力を行使できる人材によって担われ ることになる。

[問い合わせ先]

(2002年12月 9 日 受付)

東京都目黑区大岡山2-12-1

東京工菜大学大学院社会理工学研究科

桑子敏雄

TEL\&FAX : 03-5734-3256

E-mail : kuwako@valdes.titech.ac.jp

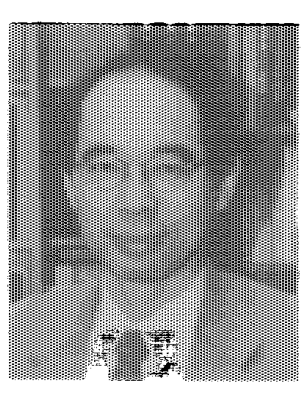

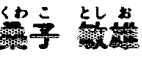
1980年 東京大学大学院人文科学研究科 哲学専修課程博士課程修了
1980年 東京大学文学部助手
1984年 南山大学文学部助教接
1989年 東京工莱大学工学部助教授
1996年 東京工学大学院社会理.T学 研究科数挍
学位博士 (文学) (東京大学 1993 年) 